Abstract 26 Table 1 A/R Reviews and Investigations

\begin{tabular}{|l|l|}
\hline $\begin{array}{l}\text { Mandatory/core reviews \& } \\
\text { investigations }\end{array}$ & $\begin{array}{l}\text { Additional reviews \& } \\
\text { investigations (as indicated) }\end{array}$ \\
\hline Overnight sleep study & Pulmonary function testing \\
\hline Medical review & Chest x-ray \\
\hline $\begin{array}{l}\text { Respiratory Physiotherapist } \\
\text { review includes peak cough flow } \\
\text { with provision of device for home } \\
\text { testing during future reviews }\end{array}$ & $\begin{array}{l}\text { Nutrition \& dietetic review - } \\
\text { planned, not currently part of the } \\
\text { pilot }\end{array}$ \\
\hline $\begin{array}{l}\text { Respiratory Clinical Nurse } \\
\text { Specialist review }\end{array}$ & $\begin{array}{l}\text { Speech \& Language therapy } \\
\text { review - planned, not currently part } \\
\text { of the pilot }\end{array}$ \\
\hline Cough swab/ secretions MC+S & $\begin{array}{l}\text { Respiratory physiologist } \\
\text { review (those using non- } \\
\text { invasive respiratory support) - } \\
\text { review of ventilator, settings, } \\
\text { servicing, mask fit, skin } \\
\text { lesions/midfacial hypoplasia }\end{array}$ \\
\hline Vit D/Ferritin & $\begin{array}{l}\text { ECG and Echocardiogram - } \\
\text { plus cardiac review if needed }\end{array}$ \\
\hline $\begin{array}{l}\text { Daytime Capillary blood gas or } \\
\text { O2/CO2 }\end{array}$ & \\
\hline
\end{tabular}

Abstract 26 Table 2 Patient demographics
\begin{tabular}{|l|l|}
\hline Diagnosis & No of patients \\
\hline Neuromuscular & \\
\hline SMA & 15 \\
\hline Congenital myasthenia & 1 \\
\hline Congenital myotonic dystrophy & 10 \\
\hline Myotubular myopathy & 3 \\
\hline Nemaline myopathy & 1 \\
\hline Kleefstra syndrome & 1 \\
\hline Duchenne Muscular Dystrophy & 1 \\
\hline Friedreich's ataxia & 1 \\
\hline Muscle eye brain disease & 2 \\
\hline Complex neurodisability & \\
\hline Undiagnosed hypotonia & 1 \\
\hline Cerebral Palsy undefined & 2 \\
\hline CTLC gene mutation & 1 \\
\hline Hypoxic ischaemic encephalopathy & 2 \\
\hline Other & 5 \\
\hline Total & 46 \\
\hline
\end{tabular}

The $\mathrm{A} / \mathrm{R}$ team met regularly to review admissions. Continuous improvement methodology was used to assess issues and implement process changes.

Key review findings were documented and shared with other teams involved. Patients and families were invited to provide feedback prior to discharge.

Results 47 AR's were performed for 46 patients. Mean age was 10.5 years (median of 11.9 years, range 1.3-17.6). $43 \%$ of patients were female.

33\% (15/46 pts) had Spinal Muscular Atrophy (See table 2 for patient demographics)

$54 \%$ of patients used nocturnal NIV, 11\% using NIV for respiratory illnesses and $13 \%$ on oxygen. 19\% had no respiratory support.

$\mathrm{A} / \mathrm{R}$ led to management changes in $59 \%$ of patients. These included microbacterial growths on sputum and commencement of treatment, airway clearance plan alterations, NIV requirement/establishment, identification of cardiomyopathy, vitamin $\mathrm{D}$ and Iron supplementation.

Patients and families scored A/R's as 9.5/10 median (8-10). Discussion This new model of individualised respiratory multidisciplinary review ensured a range of issues were identified, and treatment adjusted to optimise respiratory management for this cohort. Patients and families appeared receptive to the process.
Further analysis is needed to determine whether A/R's reduce the burden of travel by facilitating virtual reviews at other times.

The $\mathrm{A} / \mathrm{R}$ model is being expanded for children ventilated via tracheostomy and congenital central hypoventilation syndrome.

\section{ON-LINE NATIONAL SURVEY TO EXPLORE THE CHANGES IN PRACTICE OF PAEDIATRIC LONG-TERM VENTILATION}

${ }^{1}$ Heather Elphick*, ${ }^{1}$ Nicki Barker, ${ }^{2}$ Aditi Singh, ${ }^{1}$ Catherine Jesson, ${ }^{2}$ Omendra Narayan. 'Sheffield Children's Hospital NHS Foundation Trust, Sheffield, UK; ${ }^{2}$ Royal Manchester Children's Hospital, Manchester, UK

\subsection{6/bmiresp-2021-bssconf.24}

Background Long term ventilation (LTV) refers to mechanical support for breathing either at home or in hospital, for all or part of the day, for at least 3 months. Two national surveys carried out in 1998 and 2008, highlighted the increasing numbers of ventilator dependent children throughout the UK . Our objective was to collect current information about children receiving LTV in the UK, 10 years after the last national survey.

Methods All LTV centres in the UK completed a single time point census survey on 30th September 2019 using an electronic questionnaire. Data included the child's location, underlying diagnosis, interface and type of respiratory support, and whether disease-modifying drugs affected the decision to initiate LTV in specific groups within this target population.

Results Data was collected from 25 LTV centres. The total study population was 2383 children and young people. The median age of the overall sample was $\mathrm{x}$ (range $\mathrm{x}-\mathrm{x}$ ). $40.3 \%$ female; $57.2 \%$ of those recorded were male. Diagnoses were $417(17.5 \%)$ central nervous system, 692 (29\%) musculoskeletal and $1274(53.5 \%)$ a respiratory, of which $31.8 \%$ of the total had upper airway obstruction. Notable changes since 1998 were the decline in the use of 24-hour ventilation, negative pressure ventilation and tracheostomy as an interface, and the increase in the proportion of patients treated at home. 115 children had received a disease-modifying drug. The use of Ataluren and Myozme did not influence the decision to treat with LTV, but in $35 \%$ of the children treated with Nusinersin the clinician stated that the use of this drug had or may have influenced their decision to initiate LTV.

Conclusion The number of children being treated with LTV has increased by $250 \%$ in the last 10 years with notable changes in practice over the last 20 years.

\section{THE IMPACT OF THE COVID-19 PANDEMIC ON THE SLEEP AND MENTAL WELLBEING OF CHILDREN AND YOUNG PEOPLE WITH AND WITHOUT SPECIAL EDUCATIONAL NEEDS}

${ }^{1}$ Heather Elphick*, ${ }^{2}$ Philippa Howsley, ${ }^{2}$ Nathaniel Mills, ${ }^{3}$ Lisa Artis, ${ }^{3}$ Vicki Dawson. ${ }^{1}$ Sheffield Children's Hospital, Sheffield, UK; ${ }^{2}$ NIHR Children and Young People MedTech Cooperative, Sheffield, UK; ${ }^{3}$ The Sleep Charity, UK

\subsection{6/bmjresp-2021-bssconf.25}

Background Children and young people (CYP) with special educational needs (SEN) are more likely to experience disturbed sleep and poorer mental wellbeing. This study explored 